ISSN 0258-7122

Bangladesh J. Agril. Res. 34(4) : 633-643, December 2009

\title{
CONTRIBUTION OF RICE STRAW TO POTASSIUM SUPPLY IN RICE- FALLOW-RICE CROPPING PATTERN
}

\author{
P. K. SAHA ${ }^{1}$, M. A. M. MIAH ${ }^{2}$, A. T. M. S. HOSSAIN ${ }^{3}$ \\ F. RAHMAN ${ }^{4}$ AND M. A. SALEQUE ${ }^{5}$
}

\begin{abstract}
A field experiment was conducted through 2001-2004 at the Bangladesh Rice Research Institute (BRRI), Gazipur Farm with a view to determining the contribution of rice straw to K supply and K-use efficiency for the next crop in Rice-Fallow-Rice cropping pattern. Two levels of chemical potassium-0 $\left(\mathrm{K}_{0}\right)$ and $66 \mathrm{~kg} \mathrm{~K} / \mathrm{ha}\left(\mathrm{K}_{66}\right)$ from muriate of potash (MoP)- were tested with or without straw incorporation. Results showed that the use of $\mathrm{K}$ either from inorganic fertilizer or from rice straw increased the plant height, panicles $/ \mathrm{m}^{2}$, grain and straw yields of rice in both Boro and T. Aman seasons. However, the effect of $\mathrm{K}$ was more distinct in Boro season. On an average, $1.33 \mathrm{t} /$ ha yield benefit of Boro rice was obtained with rice straw incorporation in $\mathrm{K}_{0}$ plot. Application of $\mathrm{K}$ significantly increased the total $\mathrm{K}$ and $\mathrm{P}$ uptake of rice crops. Agronomic efficiency, partial factor productivity and physiological efficiency of $\mathrm{K}$ decreased with the increasing $\mathrm{K}$ level regardless of $\mathrm{K}$ sources in Boro season. Potassium replenishment through chemical fertilizer was not sufficient to balance K. However, incorporation of rice straw showed a positive $\mathrm{K}$ balance. Positive perceptible changes in soil characteristics and soil nutrient status (N, P and $\mathrm{K}$ ) were observed due to $\mathrm{K}$ fertilization either from inorganic (MoP) or from organic sources.
\end{abstract}

Key Words: Contribution of rice straw application, K-supply, rice-fallow-rice cropping pattern.

\section{Introduction}

Potassium is a major plant nutrient and its requirement for rice is quite high, even greater than that of $\mathrm{N}$. Rice crop removes about $100 \mathrm{~kg} \mathrm{~K}$ for a yield level of 5 $\mathrm{t} / \mathrm{ha}$. The general recommendation of $\mathrm{K}$ fertilizer for rice is often less than 100 $\mathrm{kg} / \mathrm{ha}$ that causes mining of soil $\mathrm{K}$. The K reserve of any soil is certainly limited, and no soil can supply $\mathrm{K}$ to crops adequately for an indefinite period of time. Some studies on K buffering capacity, K-depletion, $\mathrm{K}$ release pattern and Q/1 relationships of some soils indicated that there is difference in soils in immediate and long-term availability of K (Progress Report, 1991). Intensive cropping and use of modern rice varieties for high yield caused heavy depletion of $\mathrm{K}$ in soils, particularly in the absence of $\mathrm{K}$ application (Tiwari, 1985). Nutrient balance study indicated a negative balance for $\mathrm{N}$ and $\mathrm{K}$ and the mining of $\mathrm{K}$ from

\footnotetext{
${ }^{1 \& 5}$ Principal Scientific Officer, Soil Science Division, BRRI, Joydebpur, Gazipur 1701, ${ }^{2}$ Chief Scientific Officer, Soil Science Division, BRRI, Joydebpur, Gazipur 1701, ${ }^{3 \& 4}$ Scientific Officer, Soil Science Division, BRRI, Gazipur 1701, Bangladesh.
} 
Bangladesh soil is now in alarming situation. The value varied between 0 to -50 $\mathrm{kg} / \mathrm{ha} / \mathrm{yr}$ for $\mathrm{N}$ and-100 to-225 kg/ha/yr for K (Rijmpa and Islam, 2002). Mohanty and Mandal (1989) reported a negative K balance in rice systems at many sites in India. The negative K balance was observed even up to $60 \mathrm{~kg} / \mathrm{ha}$ of the applied $\mathrm{K}$ level with diminishing magnitude and suggested that an amount of about $61 \mathrm{~kg}$ $\mathrm{K} / \mathrm{ha}$ would be required to sustain soil native $\mathrm{K}$ for rice cropping (Ahsan et al., 1997). On the other hand, $\mathrm{K}$ fertilizer is an import item and the country spends a huge amount of foreign exchange for its procurement.

Understanding of $\mathrm{K}$ supplying power of soil is necessary for judicious recommendation of $\mathrm{K}$ fertilizer compromising economic return and maintaining soil $\mathrm{K}$ reserve. However, crop residues, especially rice straw accumulate about $70-80 \%$ of total absorbed $\mathrm{K}$ and its recycling would substantially save inorganic fertilizer and help soil $\mathrm{K}$ sustainability. Considering these points in mind, the experiment was conducted with a view to determining the potassium supplying capacity of soil of BRRI, Gazipur farm and to determine the contribution of rice straw to K supply and K use efficiency for the next crop and finally the yield of rice.

\section{Materials and Method}

The experiment was initiated in Boro 2001 at the BRRI Farm, Gazipur (AEZ-28, land type - MHL) and was continued up to 2004. During the four years of experiment, four Boro and four T. Aman crops were grown. The soil of experimental field was clay-loam in texture having slightly acidic nature $(\mathrm{pH}$ $6.03 \pm 0.02$ ). Organic $\mathrm{C}$, total $\mathrm{N}$, available $\mathrm{P}$ and exchangeable $\mathrm{K}$ of the soil was $(1.16 \pm 0.02) \%,(0.11 \pm 0.01) \%,(9.69 \pm 1.19) \mathrm{ppm}$ and $(0.22 \pm 0.00) \mathrm{meq} / 100 \mathrm{~g}$ soil, respectively. The available $\mathrm{S}, \mathrm{Zn}, \mathrm{Fe}, \mathrm{Mn}$ and $\mathrm{Cu}$ of the soil was (15.98 \pm 0.86) ppm, $(2.69+0.10) \mathrm{ppm},(114.33 \pm 0.58) \mathrm{ppm},(69.29 \pm 2.24) \mathrm{ppm}$ and (5.17 \pm 0.08$)$ ppm, respectively.

The following four treatments were tested in all seasons throughout the experimental period: $\mathrm{T}_{1} \mathrm{~K}_{0}$ (Straw removed); $\mathrm{T}_{2} \mathrm{~K}_{66}$ (Straw removed); $\mathrm{T}_{3}=\mathrm{K}_{0}$ (Straw retained) and $\mathrm{T}_{4}=\mathrm{K}_{66}$ (Straw retained). The straw yielded in Boro and $\mathrm{T}$. Aman seasons (presented in Table 2) was added to the successive T. Aman and Boro crops, respectively in $\mathrm{T}_{3}=\mathrm{K}_{0}$ (Straw retained) and $\mathrm{T}_{4}=\mathrm{K}_{66}$ (Straw retained) treatments in situ. About 5.85 and 6.58 t/ha Boro rice straw ((average of four years (2001-2004)) as oven dry basis was added to the soil in treatment $T_{3}=K_{0}$ (Straw retained) and $\mathrm{T}_{4}=\mathrm{K}_{66}$ (Straw retained), respectively in $\mathrm{T}$. Aman season. In Boro season, about 5.0 t/ha T. Aman rice straw (average of three years (20012003)) as oven dry basis was added to the soil in both treatments $T_{3}=K_{0}$ (Straw retained) and $\mathrm{T}_{4}=\mathrm{K}_{66}$ (Straw retained). The amount of $\mathrm{N}, \mathrm{P}, \mathrm{K}$ and $\mathrm{S}$ added from rice straw was presented in Table 2. Rice straw was chopped and then incorporated into soil at ploughing at 15 days before transplanting. Boro 2001 
was the first crop of the experiment and rice straw was not incorporated in that crop. BRRI dhan29 in Boro and BRRI dhan39 in T. Aman were tested. Two or three rice seedlings/hill were transplanted at $20 \times 20 \mathrm{~cm}$ spacing. Nitrogen, P and $\mathrm{S}$ were applied on the soil test basis (STB). Nitrogen fertilizer was applied into 3 splits: $1 / 3$ rd as basal, $1 / 3$ rd at active tillering stage and the rest $1 / 3$ rd at 7 days before panicle initiation stage. All other fertilizers (PKS) were applied at final land preparation. The experiment was laid out in a randomized complete block (RCB) design with 4 replications. Appropriate cultural and management practices including plant protection measures were followed during each growing season. At maturity, plant height, number of panicles and straw yield were recorded from 16 hills. The crop was harvested from $5 \mathrm{~m}^{2}$ area at the centre of each plot and the grain yield was adjusted at $14 \%$ moisture content. The rice straw yield was adjusted at oven dry basis. Soil and plant samples were analyzed using standard analytical procedures (Black, C. A. 1965; Jackson, M. L. 1962; Olsen et al., 1954; Page et al., 1982 and Yoshida et al., 1972). The obtained data were statistically analyzed using IRRISTAT version 4.1 (IRRI, 1998). Economic analyses were done using standard procedure.

\section{Results and Discussion}

\section{Growth and yields}

The application of $\mathrm{K}$ fertilizer either alone or in combination with rice straw positively influenced the plant height in both Boro and T. Aman season, while no beneficial effect of $\mathrm{K}$ fertilization was observed on panicle production in any season during study period (Table 1). The grain yield of Boro rice increased significantly either with the application of inorganic $\mathrm{K}$ fertilizer alone or in combination with rice straw throughout the study period. The highest grain yield in Boro season was obtained with the application of $66 \mathrm{~kg} \mathrm{~K} / \mathrm{ha}$ along with rice straw incorporation and the lowest with $\mathrm{K}_{0}$ treatment where rice straw was not incorporated (Table 2). Application of rice straw in $\mathrm{K}_{0}$ plot significantly increased the grain yield of Boro rice. From the four years' average yield of Boro rice, it appeared that application of rice straw alone contributed substantially to the grain yield and produced $1.33 \mathrm{t} / \mathrm{ha}$ higher mean yield than that of $\mathrm{K}$ control plot (Table 2). Similar increase in grain yield due to straw application was also reported by Ponnamperuma (1984) and Verma and Bhagat (1992). The application of $\mathrm{K}$ fertilizer either alone or in combination with rice straw did not exhibit any positive influence on the grain yield of rice in any T. Aman season during the study period. However, applied $\mathrm{K}$ irrespective of sources produced slightly elevated 4 years average grain yield than that of K control plot. Similar trend of straw yield response to K application was observed throughout the study period. 
Table 1. Effect of $\mathbf{K}$ fertilization on some growth parameters of Boro rice (BRRI dhan29) and T. Aman rice (BRRI dhan39) in a Boro-fallow- T. Aman rice cropping sequence, BRRI, Gazipur, 2001-2004.

\begin{tabular}{|c|c|c|c|c|c|c|c|c|c|c|}
\hline \multirow{2}{*}{ Treatment } & \multicolumn{5}{|c|}{ Plant height $(\mathrm{cm})$} & \multicolumn{5}{|c|}{ Panicle no. $/ \mathrm{m}^{2}$} \\
\hline & 2001 & 2002 & 2003 & 2004 & Mean & 2001 & 2002 & 2003 & 2004 & Mean \\
\hline \multicolumn{11}{|c|}{ Boro rice } \\
\hline $\mathrm{K}_{0}$ (S rem) & 103 & 88 & 80 & 82 & 88 & 365 & 334 & 306 & 308 & 328 \\
\hline $\mathrm{K}_{66}$ (S rem) & 110 & 93 & 91 & 89 & 96 & 329 & 348 & 291 & 312 & 320 \\
\hline $\mathrm{K}_{0}$ (S ret.) & 102 & 93 & 91 & 94 & 95 & 363 & 299 & 344 & 324 & 333 \\
\hline $\mathrm{K}_{66}$ (S ret) & 110 & 88 & 96 & 93 & 97 & 326 & 318 & 311 & 315 & 318 \\
\hline LSD (0.05) & 5 & NS & 2.6 & 4.8 & - & 34 & NS & NS & NS & - \\
\hline $\mathrm{CV}(\%)$ & 2.8 & 3.9 & 1.8 & 3.4 & - & 6.1 & 7.0 & 10.6 & 6.8 & - \\
\hline \multicolumn{11}{|c|}{ T. Aman rice } \\
\hline $\mathrm{K}_{0}$ (S rem) & 109 & 101 & n.d. & 83 & 98 & 245 & 222 & n.d. & 198 & 222 \\
\hline $\mathrm{K}_{66}$ (S rem) & 118 & 105 & n.d. & 94 & 106 & 223 & 207 & n.d. & 202 & 211 \\
\hline $\mathrm{K}_{0}$ (S ret.) & 112 & 107 & n.d. & 91 & 103 & 260 & 202 & n.d. & 202 & 221 \\
\hline $\mathrm{K}_{66}$ (S ret) & 117 & 108 & n.d. & & 107 & 223 & 191 & n.d. & 211 & 208 \\
\hline LSD (0.05) & 5 & 4 & - & 3.9 & & 25 & NS & - & NS & - \\
\hline CV (\%) & 2.9 & 2 & - & 2.8 & & 6.6 & 8 & - & 8.5 & - \\
\hline
\end{tabular}

Note: Plant height and panicles $/ \mathrm{m}^{2}$ data was not collected

Note: $\mathrm{S}$ rem $=$ Straw removed

$S$ ret $=$ Straw retained

n. d. $=$ not determined

\section{Nutrient content and uptake}

The $\mathrm{N}, \mathrm{P}$ and $\mathrm{K}$ content in rice grain and $\mathrm{N}$ and $\mathrm{P}$ content in rice straw were not influenced by $\mathrm{K}$ fertilization in any season, while application of $\mathrm{K}$ fertilizer either as chemical $\mathrm{K}$ or rice straw or in combination of both increased the $\mathrm{K}$ content of straw substantially (Table 3 ). The increase of $\mathrm{K}$ content was found more prominent in chemical $\mathrm{K}$ applied plot. The uptake of $\mathrm{P}$ and $\mathrm{K}$ were significantly influenced by $\mathrm{K}$ fertilization regardless of sources and the response of chemical $\mathrm{K}$ fertilizer was more prominent in nutrient uptake (Table 3). Similar trend of response were also observed in nutrient content and uptake of T. Aman rice during study period (Table 3).

\section{Potassium use efficiency}

In both the Boro and T. Aman seasons, agronomic efficiency (kilogram grain yield increase per kilogram of applied K), physiological efficiency of $\mathrm{K}$ (kilogram grain yield increase per kilogram absorbed $\mathrm{K}$ from the applied $\mathrm{K}$ by the crop) and partial factor productivity (total grain yield (kg) per kg applied K) decreased with increasing $\mathrm{K}$ level regardless of $\mathrm{K}$ sources. In Boro season, 
agronomic efficiency varied from 4 [K $\mathrm{K}_{66}$ (Straw retained)] to $16\left[\mathrm{~K}_{66}\right.$ (Straw removed)] and in T. Aman season it varied from -0.12 [K $\mathrm{K}_{66}$ (Straw retained)] to 9 $\left[\mathrm{K}_{66}\right.$ (Straw removed)]. In Boro season, physiological efficiency of $\mathrm{K}$ varied from $13\left[\mathrm{~K}_{66}\right.$ (Straw retained)] to $34\left[\mathrm{~K}_{66}\right.$ (Straw removed)], while in $\mathrm{T}$. Aman season, it varied from $-5\left[\mathrm{~K}_{0}\right.$ (Straw retained)] to 16 [K $\mathrm{K}_{66}$ (Straw removed)]. In Boro season, partial factor productivity varied from 37 [K $\mathrm{K}_{66}$ (Straw retained)] to 113 $\left[\mathrm{K}_{66}\right.$ (Straw removed)], while in T. Aman season, it varied from $20\left[\mathrm{~K}_{66}\right.$ (Straw retained)] to $61\left[\mathrm{~K}_{0}\right.$ (Straw retained)]. The highest agronomic efficiency and physiological efficiency was observed with the treatment $66 \mathrm{~kg} \mathrm{~K} / \mathrm{ha}$ without rice straw incorporation in both the seasons. Nevertheless, the application of $\mathrm{K}$ in combination with rice straw did not influence the agronomic and physiological efficiencies of $\mathrm{K}$ in $\mathrm{T}$. Aman season.

Table 2. Effect of $\mathrm{K}$ fertilization on the yield of Boro rice (BRRI dhan29) and $\mathrm{T}$. Aman rice (BRRI dhan39) in a Boro-fallow- T. Aman rice cropping sequence, BRRI farm, Gazipur, 2001-2004.

\begin{tabular}{|c|c|c|c|c|c|c|c|c|c|c|}
\hline \multirow{3}{*}{ Treatment } & \multicolumn{10}{|c|}{ Yield (t/ha) } \\
\hline & \multicolumn{5}{|c|}{ Grain } & \multicolumn{5}{|c|}{ Straw } \\
\hline & 2001 & 2002 & 2003 & 2004 & Mean & 2001 & 2002 & 2003 & 2004 & Mean \\
\hline \multicolumn{11}{|c|}{ Boro rice } \\
\hline $\mathrm{K}_{0}(\mathrm{~S}$ rem $)$ & 6.11 & 6.41 & 4.74 & 4.40 & 5.20 & 6.30 & 5.35 & 4.08 & 4.50 & 5.05 \\
\hline $\mathrm{K}_{66}$ (S rem) & 6.72 & 7.47 & 6.55 & 5.65 & 6.60 & 7.82 & 5.98 & 4.84 & 6.02 & 6.12 \\
\hline $\mathrm{K}_{0}$ (S ret.) & 6.22 & 6.86 & 6.92 & 6.10 & 6.53 & 5.93 & 5.45 & 5.54 & 6.51 & 5.85 \\
\hline $\mathrm{K}_{66}$ (S ret) & 6.78 & 7.22 & 7.16 & 6.32 & 6.87 & 7.49 & 6.38 & 5.76 & 6.72 & 6.58 \\
\hline LSD (0.05) & 0.37 & 0.49 & 0.72 & 0.14 & - & 0.83 & 0.69 & 0.63 & 0.62 & - \\
\hline CV(\%) & 3.6 & 4.3 & 7.10 & 1.6 & - & 7.6 & 7.4 & 7.80 & 6.2 & - \\
\hline \multicolumn{11}{|c|}{ T. Aman rice } \\
\hline $\mathrm{K}_{0}$ (S rem) & 3.86 & 3.30 & 3.16 & 2.23 & 3.14 & 4.48 & 4.59 & 3.07 & 2.76 & 3.72 \\
\hline $\mathrm{K}_{66}$ (S rem) & 3.53 & 3.87 & 3.57 & 3.00 & 3.54 & 4.34 & 5.05 & 3.46 & 3.52 & 4.00 \\
\hline $\mathrm{K}_{0}$ (S ret.) & 3.72 & 3.23 & 3.86 & 2.55 & 3.34 & 4.67 & 5.67 & 4.47 & 2.75 & 4.34 \\
\hline $\mathrm{K}_{66}$ (S ret) & 3.20 & 3.28 & 4.53 & 3.00 & 3.58 & 5.60 & 5.65 & 4.13 & 3.48 & 4.71 \\
\hline LSD (0.05) & 0.46 & 0.36 & 0.30 & NS & - & 1.10 & NS & NS & 0.49 & - \\
\hline CV (\%) & 8.0 & 7.80 & 6.20 & 16.40 & - & 14.4 & 11.70 & 8.40 & 10.20 & - \\
\hline
\end{tabular}

Note: A flat dose for Boro rice: $126-24$-16 kg N-P-S /ha and for T. Aman rice: 83-15 -20 $\mathrm{kg}$ N-P-S /ha

Note: $\mathrm{S}$ rem $=$ Straw removed

$S$ ret $=$ Straw retained

Note: The amount of N, P, K and S added from rice straw was as follows:

In T. Aman season (from Boro rice straw) in $\mathrm{T}_{3}=\mathrm{K}_{0}$ (straw retained) treatment: 30-5-51$5 \mathrm{Kg}$ N-P-K-S /ha and in $\mathrm{T}_{4}=\mathrm{K}_{0}$ (straw retained) treatment: 34-6-93-6 Kg N-P-K-S/ha. In Boro season (from $\mathrm{T}$. Aman rice straw) in $\mathrm{T}_{3}=\mathrm{K}_{0}$ (straw retained) treatment: 38-5-65-5 $\mathrm{kg}$ N-P-K-S /ha and in $\mathrm{T}_{4}=\mathrm{K}_{0}$ (straw retained) treatment: 42-7-98-5 kg N-P-K-S/ha. 
Table 3. Effect of $K$ fertilization on the nutrient content and uptake of Boro and $T$. Aman rice in a Rice-fallow-Rice cropping sequence, BRRI Farm, Gazipur, 2001-2002.

\begin{tabular}{|c|c|c|c|c|c|c|c|c|c|c|c|c|c|c|c|c|c|c|}
\hline \multirow{3}{*}{ Treatment } & \multicolumn{9}{|c|}{2001} & \multicolumn{9}{|c|}{2002} \\
\hline & \multicolumn{3}{|c|}{$\begin{array}{l}\text { Nutrient content } \\
\text { (\%) in grain }\end{array}$} & \multicolumn{3}{|c|}{$\begin{array}{l}\text { Nutrient content } \\
(\%) \text { in straw }\end{array}$} & \multicolumn{3}{|c|}{$\begin{array}{l}\text { Nutrient uptake } \\
\text { (kg/ha) }\end{array}$} & \multicolumn{3}{|c|}{$\begin{array}{l}\text { Nutrient content } \\
\text { (\%) in grain }\end{array}$} & \multicolumn{3}{|c|}{$\begin{array}{l}\text { Nutrient content } \\
(\%) \text { in straw }\end{array}$} & \multicolumn{3}{|c|}{$\begin{array}{c}\text { Nutrient uptake } \\
(\mathrm{kg} / \mathrm{ha})\end{array}$} \\
\hline & $\mathrm{N}$ & $\mathrm{P}$ & K & $\mathrm{N}$ & $\mathrm{P}$ & K & $\mathrm{N}$ & $\mathrm{P}$ & K & $\mathrm{N}$ & $\mathrm{P}$ & K & $\mathrm{N}$ & $\mathrm{P}$ & K & $\mathrm{N}$ & $\mathrm{P}$ & $\mathrm{K}$ \\
\hline \multicolumn{19}{|c|}{ Boro rice (BRRI dhana29) } \\
\hline $\mathrm{K}_{0}$ (S rem) & 0.98 & 0.24 & 0.23 & 0.56 & 0.08 & 0.72 & 95 & 20 & 59 & 0.94 & 0.29 & 0.23 & 0.59 & 0.10 & 0.70 & 92 & 24 & 52 \\
\hline $\mathrm{K}_{66}$ (S rem) & 0.98 & 0.25 & 0.24 & 0.51 & 0.09 & 1.47 & 106 & 24 & 132 & 0.95 & 0.29 & 0.23 & 0.48 & 0.09 & 1.11 & 99 & 27 & 83 \\
\hline $\mathrm{K}_{0}$ (S ret) & 1.02 & 0.25 & 0.24 & 0.49 & 0.08 & 0.79 & 92 & 21 & 62 & 1.00 & 0.29 & 0.24 & 0.53 & 0.09 & 0.96 & 97 & 24 & 69 \\
\hline $\mathrm{K}_{66}$ (S ret.) & 0.95 & 0.27 & 0.25 & 0.50 & 0.08 & 1.30 & 102 & 25 & 114 & 0.90 & 0.28 & 0.24 & 0.53 & 0.11 & 1.51 & 98 & 27 & 113 \\
\hline LSD (0.05) & ns & ns & ns & ns & ns & 0.25 & ns & 2.3 & 26.1 & ns & ns & ns & ns & ns & 0.35 & ns & 2.0 & 21.4 \\
\hline CV (\%) & 9.4 & 6.3 & 4.5 & 19.1 & 16.3 & 14.4 & 11.4 & 6.4 & 17.8 & 8.8 & 5.4 & 5.0 & 10.9 & 11.1 & 20.2 & 7.8 & 7.8 & 16.9 \\
\hline \multicolumn{19}{|c|}{ T. Aman rice (BRRI dhan39) } \\
\hline $\mathrm{K}_{0}$ (S rem) & 1.27 & 0.27 & 0.35 & 0.66 & 0.09 & 1.83 & 78 & 15 & 96 & 1.30 & 0.27 & 0.18 & 0.66 & 0.11 & 0.69 & 73 & 14 & 38 \\
\hline $\mathrm{K}_{66}$ (S rem) & 1.15 & 0.29 & 0.36 & 0.83 & 0.12 & 2.07 & 77 & 15 & 102 & 1.18 & 0.30 & 0.19 & 0.60 & 0.11 & 1.14 & 70 & 15 & 74 \\
\hline $\mathrm{K}_{0}$ (S ret.) & 1.19 & 0.27 & 0.34 & 0.85 & 0.09 & 1.77 & 84 & 14 & 96 & 1.20 & 0.27 & 0.20 & 0.65 & 1.12 & 0.81 & 76 & 15 & 53 \\
\hline $\mathrm{K}_{66}$ (S ret.) & 1.19 & 0.29 & 0.41 & 0.87 & 0.11 & 2.31 & 87 & 16 & 144 & 1.16 & 0.30 & 0.20 & 0.80 & 0.15 & 1.61 & 72 & 15 & 96 \\
\hline LSD (0.05) & ns & ns & ns & 0.09 & ns & 0.21 & ns & ns & 32 & ns & 0.01 & ns & ns & ns & 0.23 & ns & ns & 18.5 \\
\hline CV (\%) & 6.5 & 10.6 & 11.7 & 6.8 & 11.9 & 6.7 & 9.8 & 13.0 & 18.5 & 10.2 & 2.6 & 9.0 & 13.4 & 14.3 & 13.3 & 11 & 9.7 & 17.8 \\
\hline
\end{tabular}




\section{Apparent $\mathrm{K}$ balance in soil}

Potassium replenishment through chemical fertilizer was not sufficient to balance $\mathrm{K}$ removal by crops since much of the applied $\mathrm{K}$ was used by crops. The $\mathrm{K}$ balance thus, -76 to $-11 \mathrm{~kg} / \mathrm{ha} / \mathrm{yr}$ appeared to have been removed in excess of the amounts added (Table 4). However, $\mathrm{K}_{0}$ (straw retained) and $\mathrm{K}_{66}$ (straw retained) plot showed a positive balance of $\mathrm{K}$.

Table 4. Effect of $K$ fertilization alone or in combination with rice straw on the $K$ nutrient balance $(\mathrm{kg} / \mathrm{ha} / \mathrm{yr})$ in a rice-fallow-rice cropping sequence, BRRI, Gazipur, 2002.

\begin{tabular}{l|l|l|l|l|l}
\hline \multirow{2}{*}{ Treatments } & \multirow{2}{*}{$\begin{array}{c}\text { K added } \\
(\mathrm{kg} / \mathrm{ha} / \mathrm{yr})\end{array}$} & \multicolumn{2}{c|}{ K uptake $(\mathrm{kg} / \mathrm{ha})$} & \multirow{2}{*}{$\begin{array}{c}\text { Total uptake } \\
(\mathrm{kg} / \mathrm{ha} / \mathrm{yr})\end{array}$} & $\begin{array}{c}\text { K balance } \\
(\mathrm{kg} / \mathrm{ha} / \mathrm{yr})\end{array}$ \\
\cline { 5 - 6 } & $14^{*}$ & 52 & 38 & 90 & -76 \\
$\mathrm{~K}_{0}$ (Straw removed) & 146 & 83 & 74 & 157 & -11 \\
$\mathrm{~K}_{66}$ (Straw removed) & 146 & 69 & 52 & 121 & 29 \\
$\mathrm{~K}_{0}$ (Straw retained) & 150 & 113 & 96 & 209 & 163 \\
$\mathrm{~K}_{66}$ (Straw retained) & 372 & & &
\end{tabular}

*Through irrigation water (Assumed water requirement in Boro 100 ha-cm and T. Aman 50 ha-cm.).

\section{Cost and return analysis}

Cost and return analysis of the experiment was done with the mean data of 4 crops. In clay loam soils at Gazipur, $\mathrm{K}_{66}$ along with rice straw @ 5.0 t/ha on oven dry basis was found as the most economic dose in terms of additional income (Tk.12282 /ha) in Boro season. The $\mathrm{K}_{66}$ dose alone gave Tk.11987/ha additional benefit which was comparable to that earned by $\mathrm{K}_{0+\mathrm{RS}}$ dose (Tk. $10535 / \mathrm{ha}$ ). In T. Aman season, the highest additional benefit (Tk.2292/ha) was estimated with the application of K-fertilizer @ $66 \mathrm{~kg} \mathrm{K/ha}$ followed by $\mathrm{K}_{66+\mathrm{RS}}$ dose (Table 5). It is noted that the additional income earned due to K-fertilization was much more in Boro rice than that of T. Aman rice in clay loam soils of Gazipur.

\section{Soil fertility status}

Perceptible changes in soil characteristics and soil nutrient status occurred due to $\mathrm{K}$ fertilization either from inorganic (MoP) or from organic (rice straw) sources in the Boro-Fallow-T. Aman cropping pattern (Table 6).

Table 6 showed that $\mathrm{pH}$ ranged from 6.30-6.83 at the surface layer. The initial soil $\mathrm{pH}$ was 6.03. After 4 years, $\mathrm{pH}$ increased slightly up to 6.30 , where no $\mathrm{K}$ fertilizer was applied. The use of $\mathrm{K}$ fertilizer either alone or in combination with rice straw significantly increased the $\mathrm{pH}$ value. Application of rice straw in $\mathrm{K}_{0}$ plot significantly increased the $\mathrm{pH}$ value. It might be the reason that the 
amount of soil exchangeable $\mathrm{K}$ increased in this treatment to compare with [ $\mathrm{K}_{0}$ (Straw removed)] treatment (Table 6) and as a result, it increased $\mathrm{pH}$ value. Our data confirmed the results reported by Smith et al. (1994); Michaelson and Ping (1987). They reported that soil solution $\mathrm{pH}$ is dependent on mineral weathering and mineral weathering increase $\mathrm{pH}$ by releasing $\mathrm{Ca}, \mathrm{Mg}$ and $\mathrm{K}$ (Smith et al., 1994). Another finding also reported that $\mathrm{P}$ and $\mathrm{K}$ fertilization increased $\mathrm{N}$ utilization and resulted in decreased soil acidification i.e. increased $\mathrm{pH}$ value (Michaelson and Ping, 1987).

Table 5. Additional income (per hectare basis) due to muriate of potash (MoP) and rice straw application as a source of $\mathrm{K}$ fertilizer reported from the trial in clay loam soils of BRRI Farm, Gazipur, 200 1-2004.

\begin{tabular}{|c|c|c|c|c|c|c|c|c|}
\hline \multirow{3}{*}{ Particulars } & \multicolumn{8}{|c|}{ K fertilizer (kg/ha) } \\
\hline & $\begin{array}{l}\mathrm{K}_{0}(\mathrm{~S} \\
\text { rem })\end{array}$ & $\begin{array}{c}\mathrm{K}_{66}(\mathrm{~S} \\
\text { rem })\end{array}$ & $\begin{array}{l}\mathrm{K}_{0}(\mathrm{~S} \\
\text { ret. })^{* *}\end{array}$ & $\begin{array}{c}\mathrm{K}_{66}(\mathrm{~S} \\
\text { ret })\end{array}$ & $\begin{array}{c}\mathrm{K}_{0}(\mathrm{~S} \\
\text { rem })\end{array}$ & $\begin{array}{c}\mathrm{K}_{66}(\mathrm{~S} \\
\text { rem })\end{array}$ & $\begin{array}{c}\mathrm{K}_{0}(\mathrm{~S} \\
\text { ret. })\end{array}$ & $\begin{array}{c}\mathrm{K}_{66}(\mathrm{~S} \\
\text { ret })\end{array}$ \\
\hline & \multicolumn{4}{|c|}{ Boro (mean of 4 crops) } & \multicolumn{4}{|c|}{ T. Aman (mean of 4 crops) } \\
\hline 1. Grain yield (t/ha) & 5.20 & 6.60 & 6.53 & 6.87 & 3.14 & 3.54 & 3.34 & 3.58 \\
\hline $\begin{array}{l}\text { 2. Grain yield increase } \\
(\mathrm{t} / \mathrm{ha})\end{array}$ & - & 1.40 & 1.33 & 1.67 & - & 0.40 & 0.20 & 0.44 \\
\hline 3 Straw yield (t/ha) & 5.05 & 6.12 & 5.85 & 6.58 & 3.72 & 4.00 & 4.34 & 4.71 \\
\hline $4 \begin{array}{l}\text { Straw yield increase } \\
(\mathrm{t} / \mathrm{ha})\end{array}$ & - & 1.07 & 0.80 & 1.53 & - & 0.28 & 0.62 & 0.99 \\
\hline $\begin{array}{l}\text { 5. Value of extra grain } \\
\text { production (Tk/ha, at } \\
\text { Tk. 10000/t in Aman } \\
\text { and Tk. 9500/t in } \\
\text { Boro) }\end{array}$ & - & 13300 & 12635 & 15865 & - & 4000 & 2000 & 4400 \\
\hline $\begin{array}{l}\text { 6. Value of extra straw } \\
\text { production (Tk/ha, at } \\
\text { Tk. 500/t in Aman and } \\
\text { Boro) }\end{array}$ & - & 535 & 400 & 765 & - & 140 & 310 & 495 \\
\hline $\begin{array}{l}\text { 7. Total value of extra } \\
\text { production }(\mathrm{Tk} / \mathrm{ha})\end{array}$ & - & 13835 & 13035 & 16630 & - & 4140 & 2310 & 4895 \\
\hline $\begin{array}{l}\text { 8. Cost of MOP and CR } \\
\text { (Tk./ha at Tk. } 14 \text { /kg } \\
\text { for MoP and Tk. } \\
0.5 / \mathrm{kg} \text { for CR) }\end{array}$ & - & 1848 & 2500 & 4348 & - & 1848 & 2500 & 4348 \\
\hline $\begin{array}{l}\text { 9. Additional income } \\
\text { (Tk./ha) due to K use }\end{array}$ & - & 11987 & 10535 & 12282 & - & 2292 & -190 & 547 \\
\hline 10. MBCR & - & 7.49 & 5.21 & 3.82 & - & 2.24 & 0.92 & 1.13 \\
\hline
\end{tabular}

$* \mathrm{~S}$ rem $=$ Straw removed

$* *$ S ret $=$ Straw retained

*** $\mathrm{CR}=$ Crop residues. (@ 5.0 t!ha both in Boro and T. Aman seasons 
Organic carbon in soils varied significantly as influenced by the use of $\mathrm{K}$ fertilization either from inorganic (MoP) or from organic (rice straw) sources. Organic carbon ranged from $1.05 \%$ [ $\mathrm{K}_{0}$ (Straw removed)] to $1.43 \%$ [ $\mathrm{K}_{66}$ (Straw retained)]. In the initial soil, organic carbon was $1.16 \%$, which decreased to $1.05 \%$ after 4 years in the $\mathrm{K}$ control plot $\left[\mathrm{K}_{0}\right.$ (Straw removed)]. The use of $\mathrm{K}$ fertilizer either alone or in combination with rice straw significantly increased the organic carbon level. Application of rice straw in $\mathrm{K}_{0}$ plot also significantly increased the organic carbon level. It was significantly higher than that of $\left[K_{66}\right.$ (Straw removed)]. The significantly highest percentage of organic carbon (1.43) was accumulated in treatment $\left[\mathrm{K}_{66}\right.$ (Straw retained)], where $\mathrm{K}$ was applied with rice straw. These findings support the results obtained by Surekha et al. (2004) and Ponnamperuma (1984). They reported that the increase in soil organic carbon was attributed due to the addition of straw and green manure containing higher organic carbon content and also to the slow decomposition of applied and native soil organic carbon due to prevailing anoxic condition and formation of recalcitrant (difficulty decomposable) soil organic carbon under rice - rice system.

Table 6. Postharvest soil $\mathrm{pH}$, organic carbon, and some macronutrient status ( $\mathrm{N}, \mathrm{P}$, $\mathrm{K})$ at the surface layer due to $\mathrm{K}$ fertilization used for 4 years in a ricefallow-rice cropping sequence, BRRI, Gazipur (2001-2004).

\begin{tabular}{l|l|l|l|l|l}
\hline \multicolumn{1}{c|}{ Treatment } & \multicolumn{1}{c|}{$\begin{array}{c}\mathrm{pH} \\
(1: 2.5)\end{array}$} & $\begin{array}{c}\text { Organic } \\
\text { carbon (\%) }\end{array}$ & $\begin{array}{c}\text { Total } \\
\mathrm{N}(\%)\end{array}$ & $\begin{array}{c}\text { Available } \\
\mathrm{P}(\mathrm{ppm})\end{array}$ & $\begin{array}{c}\text { Exch. K } \\
(\mathrm{meq} / 100 \mathrm{~g} \\
\text { soil) }\end{array}$ \\
\hline Ko(Strawremoved) & 6.30 & 1.05 & 0.11 & 5.79 & 0.13 \\
K66 (Straw removed) & 6.57 & 1.23 & 0.12 & 10.11 & 0.14 \\
Ko (Straw retained) & 6.75 & 1.32 & 0.13 & 8.36 & 0.14 \\
K66(Strawretained) & 6.83 & 1.43 & 0.14 & 10.74 & 0.16 \\
\hline LSD (0.05) & 0.14 & 0.06 & 0.006 & 0.71 & 0.01 \\
CV (\%) & 1.4 & 3.0 & 3.0 & 5.1 & 5.2 \\
\hline Initial soil & $6.03 \pm 0.02$ & $1.16 \pm 0.02$ & $0.11 \pm 0.01$ & $9.69 \pm 1.19$ & $0.22 \pm 0.00$ \\
\hline
\end{tabular}

Similar trend was also observed in case of soil total $\mathrm{N}$. The total $\mathrm{N}$ in soil ranged from $0.11 \%$ [initial soil $/ \mathrm{K}_{0}$ (Straw removed)] to $0.14 \%\left[\mathrm{~K}_{66}\right.$ (Straw retained)]. Like organic carbon, the significantly highest amount of total $\mathrm{N}$ was observed with $\mathrm{K}_{66}$ (Straw retained) followed by $\mathrm{K}_{0}$ (Straw retained) (Table 6). It might be due to accumulation of organic carbon. The available $\mathrm{P}$ in soil resulted from the use of $\mathrm{K}$ fertilization either from inorganic (MoP) or from organic (rice straw) sources, ranging from $8.36 \mathrm{ppm}\left[\mathrm{K}_{0}\right.$ (Straw retained)] to $10.74 \mathrm{ppm}$ [K $\mathrm{K}_{66}$ (Straw retained)] (Table 6). In the initial soil, the available P was $9.69 \mathrm{ppm}$, but after 4 years, it decreased to $5.79 \mathrm{ppm}$ in the [ $\mathrm{K}_{0}$ (Straw removed)] treatment. 
On the other hand, application of rice straw in $\mathrm{K}_{0}$ plot significantly increased available $\mathrm{P}$ to $8.36 \mathrm{ppm}$. The application of inorganic $\mathrm{K}_{66} \mathrm{~kg} / \mathrm{ha}$ alone significantly increased available $\mathrm{P}$ to $10.11 \mathrm{ppm}$, and the addition of rice straw along with it further increased available P to 10.74 ppm (Table 6).

A little influence of the $\mathrm{K}$ fertilization on the soil exchangeable $\mathrm{K}$ was observed (Table 6). The exchangeable $\mathrm{K}$ ranged from 0.13 [ $\mathrm{K}_{0}$ (Straw removed)] plot to $0.16 \mathrm{meq} / 100 \mathrm{~g}$ soil $\left(\mathrm{K}_{66}\right.$ (Straw retained)) plot. In the initial soil, exchangeable $\mathrm{K}$ was $0.22 \mathrm{meq} / 100 \mathrm{~g}$ soil. After 4 years, it dramatically decreased to $0.13 \mathrm{meq} / 100 \mathrm{~g}$ soil in the $\left[\mathrm{K}_{0}\right.$ (Straw removed)] plot, where no $\mathrm{K}$ fertilizer was added. A slightly higher amount of exchangeable $\mathrm{K}$ was observed in those plots, where inorganic $\mathrm{K}$ alone or rice straw were added in comparison with the plot, where no $\mathrm{K}$ fertilizer was added. The significantly highest amount of exchangeable $\mathrm{K}(0.16 \mathrm{meq} / 100 \mathrm{~g}$ soil $)$ was recorded with the treatment $\left[\mathrm{K}_{66}\right.$ (Straw retained)], where rice straw was incorporated along with the inorganic K @ $66 \mathrm{~kg} / \mathrm{ha}$. From this observation, it indicates that rice straw with the combination of inorganic $\mathrm{K}$ fertilizer helps to mobilize soil exchangeable $\mathrm{K}$ by $0.02 \mathrm{meq} / 100 \mathrm{~g}$ soil (Table 6). The increase in soil available $\mathrm{K}$ due to straw application was also reported by Ponnamperuma (1984) and Dobermann et al. (1998).

\section{Conclusion}

- Distinct effect of $\mathrm{K}$ fertilization either with inorganic $\mathrm{K}$ or with rice straw was observed in Boro season.

- Application of $\mathrm{K}$ fertilizer increased the plant height, grain and straw yield, $\mathrm{P}$ and $\mathrm{K}$ uptake of rice, but decreased the potassium use efficiency.

- Rice straw incorporation with inorganic K fertilizer built up $\mathrm{K}$ level in soil.

\section{References}

Ahsan, K., M. A. Saleque, M. J. Abedin and N. I. Bhuiyan. 1997. Multiple year-response of wetland rice to potassium fertilizer and apparent potassium balance in soil. Thai $J$. Agric. Sci. 30: 501-509.

Black, C. A. 1965. Methods of Soil Analysis. Part I and II. Am. Soc. Agron. Inc. Pub., Madison, USA.

Dobermann, A., K. G. Cassman, C. P. Mamaril and J. E. Sheehy. 1998. Management of phosphorus, potassium and sulfur in intensive, irrigated lowland rice. Field Crops Res. 56: 113-138.

IRRI. 1998. International Rice Research Institute Irristat for Windows, Version 4.1, Biometrics unit, International Rice Res. Inst., Philippines.

Jackson, M. L. 1962. Soil Chemical Analysis. Constable and Co. Ltd. London. 
Michaelson, C. J. and C. L. Ping. 1987. Effects of P, K, and liming on soil pH, Al, Mn, $\mathrm{K}$, and forage barley dry matter yield and quality for a newly-cleared Cryorthod. $J$. Plant and Soil 104(2):155-161.

Mohanty, S. K. and L. N.Mandal. 1989. Transformation and budgeting of N, P and K in soils for rice cultivation. Oryza. 26: 213-23 1.

Olsen, S. R, C. V. Cole, F. S. Watnabe and L. A. Dean. 1954. Estimation of available phosphorus in Soils by extraction with sodium bicarbonate. U.S. Dept. Agr. pp: 929.

Page, A. L., R. H. Miller and D. R. Keeney. 1982. Methods of Soil analysis Part 2. 2nd Ed., Am. Soc. Agron. Madison., Wisconsin, USA.

Ponnamperuma, F. N. 1984. Straw as source of nutrients for wetland rice. In Organic Matter and Rice. International Rice Research Institute. Manila, Philippines. pp. 117-136.

Progress Report. 1991. Progress Report for 1990-1991 on Potassium studies in Soils and Crops of Bangladesh (BRRI- component). Prepared for presentation in the Workshop of an on going Contract Research Project at BARC, Dhaka. Oct. 26-27, 1991.

Rijmpa, J. and F. Islam. 2002. Nutrient mining and its effect on crop production and environment. In: Seminar on soil health management: DAE-SFFP experience. DAESFFP, Khamarbari, Dhaka, Bangladesh.

Smith, C. J., M. B. Peoples, G. Keerthisinghe and T. R. James. 1994. Effects of surface applications of lime, gypsum and phosphogypsum on the alleviating of surface and subsurface acidity in a soil under pasture. Australian J. Soil Res. 32(5): 995-1008.

Surekha, K., M. Narayana Reddy, K. V. Rao and P. C. Sta Cruz. 2004. Evaluation of crop residue management practices for improving yields, nutrient balance and soil health under intensive rice-rice system. J. Indian Soc. Soil Sci. 52(4): 448-453.

Tiwari, K. N. 1985. Changes in potassium status of alluvial soils under intensive cropping. Fertilizer News. 30(9): 17-24.

Verma, T. S. and R. M. Bhagat. 1992. Impact of rice straw management practices on yield, nitrogen uptake and soil properties in a wheat -rice rotation in northern India. Fertilizer Res. 33: 97-106.

Yoshida, S., D. A. Forno, J. H. Cock, and K. A. Gomez. 1972. Laboratory manual for Physiological Studies of Rice. International Rice Research Institute (IRRI), Los Banos, Philippines. 